\title{
A LANDSCAPE PLANNING APPROACH FOR CREATING A RECREATION PARK OPEN SPACES SYSTEM (RPOSS): \\ A Study of Wadi - El-Arish Sinai Region in Egypt
}

\author{
Mohammad Hussein Refaat \\ Faculty of Urban \& Regional Planning \\ Cairo University
}

\begin{abstract}
This paper will focus on elaborating the idea of the Recreational Open Space System, and how to implement it in Egypt as a new product in the planning process in Egypt, taking Wadi AlArish in North Sinai region as an example. The main objective of this research is to introduce this concept that will help to ensure that the Regional landscape remains healthy and responds to growing demands on its resources and facilities in the Egyptian planning process.
\end{abstract}

"Open space," is defined as public and private land that is generally natural in character. It may support agricultural production, or provide outdoor recreational opportunities, or protect cultural and natural resources. It contains relatively few buildings or other humanmade structures. Depending on the location and surrounding land use, open space can range in size from a small city plaza or neighborhood park of several hundred square feet, corridors linking neighborhoods of several acres to pasture, croplands or natural areas and parks covering thousands of acres. (Fabos, J. 2004)

"Recreation Park Open Space System" (RPOSS) means land and water areas, or interests therein, and facilities determined by the metropolitan council to be of regional importance in providing for a balanced system of public outdoor recreation for the metropolitan area including but not limited to park reserves, major linear parks and trails, large recreation parks, and conservatories, zoos, and other special use facilities. Parks and open space are vital to the quality of life of residents in the region. Parks and open space benefit the individual by providing opportunities for recreation, fitness, self-discovery, and education. (Opdam, P et al., 2002) They benefit communities by serving as public gathering places, and they have been shown to reduce juvenile crime rates and increase community pride. Parks and open space have economic benefits as well, with increased values of land adjacent to parks and trails, as a stimulus for tourism, as a factor in curbing health care costs, and as a quality of life factor for retaining and attracting business to the region. Parks and open space also provide significant environmental benefits by preserving natural habitat, and by protecting and improving air and water quality.

Keywords: Landscape Planning, Regional Planning, Recreation Park Open Spaces System, AlArish, North Sinai.

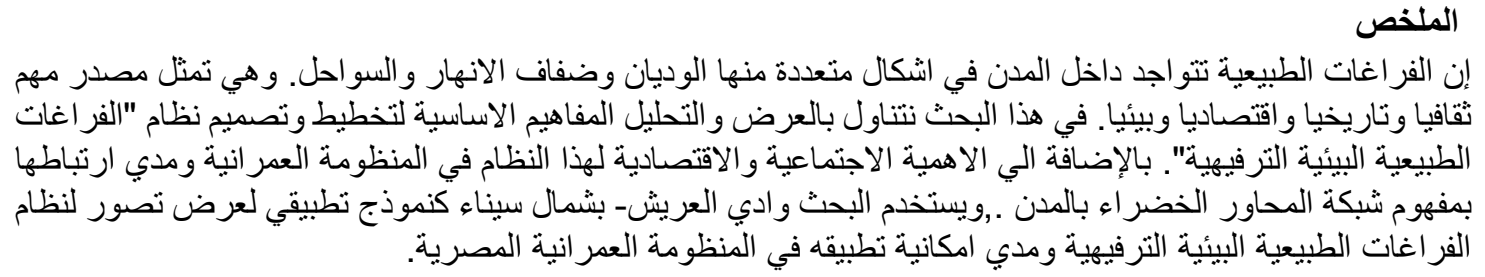




\section{EVOLUTION OF THE LANDSCAPE PLANNING PROCESS}

Landscape planning as a method for regional planning appears to have begun with the general idea of looking to nature for inspiration in decision-making about human activity. New landscapes emerge with changing life-styles. Decision making for landscape planning, conservation and management use the concept of sustainability widely. "Sustainable Landscapes" often refers to very specific applications of (landscape) ecological principles in landscape design and architecture and in landscape management and good agricultural practice. (Turner, T. 1987)

Sustainable landscape planning places physical planning in a broader perspective. We include land (re)development to consider the improvement of ecological conditions for planned land uses. We also include land management by adopting adaptive management techniques that apply monitoring as an important part of a sustainable landscape planning process. (Fabos, J. 1985)

Landscape planning was developed over the course of three quarters of a century through the work of several men. These men included, for example, Patrik Geddes, a Scottish botanist who advocated surveying an area to determine its capabilities and limitations, then developing a land use plan based on the results of the survey. Warren Manning, a landscape architect, developed the map overlay technique for conducting such surveys, in about 1913. This technique involved mapping the natural and cultural resources of a place and then overlaying the maps to identify areas suitable for certain types of lands uses, such as urbanization or agriculture. The urban historian Lewis Mumford found that unplanned urban growth and development led to such problems as cities being built on major floodplains, and advocated the use of ecological information in urban planning. Benton Mackaye took all of these ideas in the 1930's and applied them in his work with Tennessee Vally Authority as an environmental engineer. (Carpenter, R. 1989) In 1969 lan McHarg formally lay out (and popularized ecological planning as method of regional planning in his book, Design with Nature. Since the 1960s much landscape planning has been a form of 'constraint-based exclusionary planning', based largely on the work of McHarg (1969). In this defensive form of planning, resources are assessed and protected according to their intrinsic value. While this planning approach has been successful in many respects, it has proven to be ineffective in preventing landscape fragmentation.(Hackett, B. 1971) In the early 1990s, traditional approaches to natural resource management were widely considered ineffective for promoting the "new" goal of sustainability. As a consequence, ecosystem management emerged as a new paradigm for land-use management in the US, sustainability being its overall goal. An ecologically sustainable landscape provides the conditions for the long-term maintenance of that biodiversity aim. A key factor for that purpose, the spatial cohesion of the network of ecosystems is often neglected. One of the reasons for this is the knowledge gap between ecology and planning. (Opdam, 2002)

In conclusion landscape planning provides a tool by which to manage change in the landscape so as to conserve biodiversity, contributing to a more sustainable future. At the end sustainable landscape planning emerged as a natural outcome of the 
evolution of the planning discipline into the $21^{\text {st }}$ century where new social values, such as the key concepts of sustainability (solidarity between present and future generations, and the need to balance development with nature), are increasingly being recognized and embedded into planning methods and legislation. (Zube, E. et al. 1982)

\section{RECREATION PARK OPEN SPACE SYSTEM (RPOSS)}

Landscape planning, in its consideration of both the natural properties of landscapes, and the needs of the humans which interact with these landscapes, might be a means of restoring the flow of feedback between ourselves and our environment. It might allow us to improve our management of our energy income by designing agroecosystems that take advantage of natural ecosystem processes while still providing for our needs. It also, involves designing landscape management plans based on the natural ecosystem properties of the landscape in question, as well as on the needs of the humans who interact with the landscape. Landscape planning as a method has its roots in the philosophical tradition of viewing nature as teacher rather than servant, and humans as part of rather than separate from nature. (Beer, A. 1990)

It may be looked at as an holistic, interdisciplinary method of planning for landscape management. From the resultant dialogue between landscape ecologists and landscape planners a consensus is emerging that some form of ecological infrastructure is necessary to achieve a sustainable landscape condition with respect to both abiotic and biotic resources. A key component of such infrastructures is the recognition of the importance of some form of 'connections' which link isolated natural areas that remain in an increasingly fragmented megapolitan landscape. (Naveh, Z. 2000 )

An effective network of open spaces can make our cities livable by increasing economic vitality, connecting people to the natural world, promoting individual and community well-being, and sustaining natural systems. With a rapidly growing population and increased urban density, it is often hard to find extra room for green spaces. Thus, integrating different types of green spaces into the built environment is becoming a priority. (Harms, B., 1993) Recent enthusiasm, or green infrastructure planning shows that green infrastructure has become a must for academics, the public, and agencies interested in green space issues. In addition it is a way to help develop environmental thinking. (Foppen, P. Vos, C. 2002)

Green infrastructure elements may be summarized in open space systems such as parks, habitat, green roofs, street trees, eco-industrial parks, public gardens, and rain gardens. The connectivity of the system is created by combining these elements to form a network of multi-functional open spaces. The connectivity of open spaces today has been influenced by four factors: linking parks for people; linking natural areas to treat fragmentation and preserve biodiversity; identifying and protecting interconnected open spaces systems to benefit wildlife and ensure a sustainable future; and building upon the greenway movement. (Carpenter,R., 1983) 
One of the main tools of the green infra structure planning approaches is to provide a Recreational Park Open Spaces System (RPOSS). The concept of a regional park system is a foundation of the concept of Smart Growth. Regional parks make the region a more attractive place to live, work and do business. In a high-technology economy that provides businesses and workers with unprecedented mobility, amenities that add measurably to the quality of life, such as parks and natural open space, create a powerful draw for economic development. The regional park system itself is an excellent example of how some Smart Growth planning concepts have been in place for over 25 years. (Ahern, J. 1999)

The new challenge posed by a broader concept of Smart Growth is for the recreational park system to become a more integrated component of the region's park and open space system and integrated with housing and transportation.

\subsection{Economic Importance of Developing a RPOSS Strategy}

There are several economic importance when adopting the RPOSS, such as, to sustain economic growth and position the region to compete in the world economy, is a major aspect in developing the region. Promote more efficient, integrated public investments in transportation, housing, schools, parks and utilities, to make the best use of existing resources and investments. Also, Encourage wise stewardship of natural resources and conservation of agricultural land and open space. (Bastian, $\mathrm{O}$. and Röder, M. 1998)

In addition to accommodate growth in ways that maintains or enhances community livability and quality of life. It balances the diverse interests and objectives of the region's various communities; inform and engage citizens in decisions affecting the future of their community and region, and provides incentives to foster growth patterns that are sustainable and support the region's competitiveness. This will help in acting upon the need for integrating the variety of needs of the region. (Carpenter, R.,1983)

\subsection{Social Importance of Developing a RPOSS Strategy}

There are various importances for developing a Recreation Park Open Space System Strategy from improving communications and information sharing between different levels of recreation and natural resource providers. As well as communication with the affected public and communities in the master planning process. This done, so as to provide outdoor recreation, open space and greenways for residents, who choose to live in higher-density areas. (Hobbs, R., 1997)

Park monitoring, and evaluation, and long-range forecasting to help better plan for the future growth within the region. Locating and designing regional trails which may serve the dual purposes of recreation and commuting. Providing recreation opportunities to residents from across the region to promote a regional sense of community founded on appreciation for the city's unique and highly valued natural resources. Smart Growth and Parks/Open Space at the local level, parks and trails serve as public space - a space where the community can meet on common ground 
and bond through shared recreation and/or natural resource appreciation interests. (Fabos, J.G. 2004)

Town squares have historically served as epicenters for public discourse. Public spaces outside of large buildings in the downtowns provide a place for workers to read, relax, people watch and socialize. Parks, playgrounds and athletic fields provide opportunities for families to meet, and for interaction through pick-up games and sports leagues. Local undeveloped open space provides opportunities for children and adults alike to explore nature and go on adventures within their own neighborhood. Trails create linear social spaces and neighborhoods that transcend political or physical boundaries such as busy streets or highways. Planted triangles can help relieve tension from driving. (Turner,T. 1987)

The regional Smart Growth strategy recognizes the importance of parks and open space at the community level as well as the regional level. While historically the regional park system has primarily focused on the regional level of park and open space planning and management, the policies in this plan will result in greater communication and planning between the regional park system and the local communities. (Bastian, O. and Röder, M. 1998)

In conclusion, in landscape planning many different demands for often-limited space must be weighed against each other. In this weighing process, economic (especially monetary) information plays an important role and tends to dominate the decisionmaking at the expense of ecological and socio-cultural values. An important bridge to build (and to cross) is the link between ecology and economics. Since most landscape planning decisions are based on economic (especially monetary) data, better information on the economic and monetary importance of natural and seminatural ecosystems and landscapes is crucial in order to achieve more sustainable use of the landscapes and conserve the natural capital. (Jongman, A. and Troumbis, A. Y. 1996)

\section{The Formulation of a RPOSS Policy Plan}

The 'escape from the city' has now been a phenomenon for several decades, as the constraints of time, money and transport have been relaxed, whilst expanding urban areas have meant that people have had to travel further to escape city life. This has created situations in which more people seek unspoilt landscape settings within a diminishing rural area. (Andre, B. Leitao, and Ahren, J., 2002)

The public outdoor recreation system in the metropolitan area is composed of local facilities such as city and school parks/trails, county parks/trails, the regional park system, State parks/trails and wildlife areas, and federal lands. These providers also are responsible for managing natural resources within their parks and trail corridors. Additionally, there are other natural resource management agencies and groups such as watershed districts and the Metropolitan Greenways and Natural Areas program that provide important informal outdoor recreation opportunities and natural resource protection (Fabos, J.G. and Ryan, R. 2004). All of these resources are inter- 
connected and are inter-dependent. A strain on one link of the "chain" has repercussions throughout the entire system. Additionally, funding of publicly managed outdoor recreation areas and natural resources is limited, which can be mitigated through reduction of duplicative services and/or creating partnerships between different providers. It is in the best interests of public outdoor recreation system providers and the natural resource mangers in the metropolitan area to work together through open communications, information sharing and partnerships. (Andre, Leitao, and Ahren, J., 2002)

\subsection{Trails and their Role in the Development of a RPOSS}

Greenways represent a distinctly strategic approach to landscape planning. It is not a model for comprehensive landscape planning, because it focuses on networks and linear areas, which are implicitly nested within a larger landscape context. While greenway planning is conscious of landscape context, it focuses on the strategy of achieving multiple benefits through combinations of spatially and functionally compatible land uses within a network. (GENG Zhe et al. 2010)

It is desirable to have a comprehensive network of trails that serves both recreation and transportation needs. This network links State, regional, county and local trails together, and integrates the trail system with other transportation modes such as the bus and light rail transit systems. Regional trails are primarily recreation trails, though some of the urban regional trails also have important commuter functions. County and local trails serve as recreation and transportation routes for the immediate local population. They may also serve as "feeder" trails into the larger regional system of trails. To help integrate the network, the Council is responsible for reviewing the comprehensive plans of all cities and townships within the metropolitan area (YU Hong et al., 2009). This review includes an assessment of local trails and their relationship to the regional trail and transit systems transportation system strive to work in unison when developing trail and transportation plans. Recreational use of corridors may be combined with non-motorized commuter use and transit. This mixed use is desirable as it results in lower costs while serving the greatest number of residents. Occasionally existing linear space previously used for railroad or road transportation becomes available for new uses. The availability of these corridors offers potentially excellent opportunities for the regional trail system to expeditiously acquire links that would otherwise have to be assembled on a parcel-by-parcel basis (Fabos, J.G. and Ryan, R. 2004). All surplus corridors put on the market should be evaluated for their suitability as additions to the regional trail system. If the available corridor traverses an area with high quality natural resources or it constitutes part of a link in a more extensive regional trail system; there is interest in acquiring the trail for use as part of the regional trail system. In some cases, available corridors do not provide any linkages, nor do they offer any potentially interesting trail recreation experience. In these cases, the regional park system has little interest in acquisition or use of the corridor. (GENG Zhe et al. 2010) The regional activities selected require large tracts of land or land endowed with unique natural resources or both. The land needs are easier to meet at the regional level than at the municipal level, and the associated activities are more 
likely to be developed or provided at a regional level than by cities and towns. Also a study of how the vegetation will be managed should be carried out. Vegetation management is important for maintaining water quality, preserving plants, and providing bird and wildlife habitat. It involves protection of old growth trees and rare and endangered plant species, control of exotic species. (Fahrig, L. 1999)

\subsection{Recreation facilities proposed for inclusion in the RPOSS}

While developing a recreational park open spaces system units should be based on the principle of providing and maintaining quality public park areas and facilities primarily for citizens of the metropolitan area. The individual master plan process will balance the need to provide facilities in the park with the impacts of those facilities and their use on the natural resources in the park.

According to (Li, B. L. 2000), the following items should be included in developing or redeveloping of a Recreation Park Open Space System plan:

1. Projects that provide new facilities rehabilitate facilities or increase capacity where there is documented existing or projected high use, and where there will be no adverse effect on the natural resource base.

2. Projects continuing a phased high-priority project or one of relatively high-priority that is timed with other public improvement projects to achieve significant economies in cost of construction.

3. Projects providing a specific facility that meets documented needs are currently not available or are significantly underrepresented in the system where there will be no adverse effect on the natural resource base.

4. Projects to serve planned future use in a location with no adverse effects on the natural resource base.

5. For regional trails, implementing agencies are encouraged to connect existing trails to other trails or regional facilities or extend existing trails.

6. Funding the construction phase of a project that follows a funded design/engineering phase of that project has a higher priority than funding reimbursement projects.

7. Natural resource restoration, invasive species control and other types of resource restoration and protection projects.

In conclusion, landscape planning plans based on systematic use of ecological knowledge generates ecologically more sustainable landscapes, as large parts of today's landscape especially lack unique and peculiar structures. Thus, the sense of place has gone, and landscape has lost its ability to tell specific and individual stories to the beholder. The planning process should not be seen as a vehicle by which to achieve a final solution. Rather, it is a process through which to build consensus, political and public support, to resolve differences between local communities and between public agencies and private business interests. A plan cannot answer all the detailed questions, and it cannot anticipate all the changes in circumstances which will 
occur over time. What it can do is build support and define a broad direction-the parameters for managing biodiversity in the landscape. The plan should build political consensus and public support through an open and accountable process. (Takeuchi, K. and Lee, D.-K. 1989)

\section{WADI AL-ARISH SINAI REGION AS A MODEL IN APPLYING RPOSS}

\subsection{Urban Morphology of Wadi Al-Arish, North Sinai Region}

Over the past 30 years Sinai has become a tourist destination due to its natural setting, rich coral reefs, and biblical history. The most popular tourist destination in Sinai are Mount Sinai (Jabal Musa) and St. Catherine's Monastery, which is considered to be the oldest working Christian monastery in the world, and the beach resorts of Sharm elSheikh, Dahab, Nuweiba and Taba. Most of the Sinai Peninsula is divided among two Egyptian governorates, or provinces, named Ganub Sina (South Sinai) and Shamal Sina (North Sinai). Approximately 66,500 people live in Ganub Sina and 314,000 live in Shamal Sina. (Dames and Moore 1984)

Al-Arish city (Figure 1) is the capital and largest city (with 114,900 inhabitants as of 2002) of the Egyptian governorate of North Sinai, as well as the largest city on the entire Sinai Peninsula, lying on the Mediterranean coast of the Sinai peninsula, 344 kilometers (214 mi) northeast of Cairo.

Figure (1) Location and setting of Al-Arish City within the Sinai Region (GOPP, 2010)
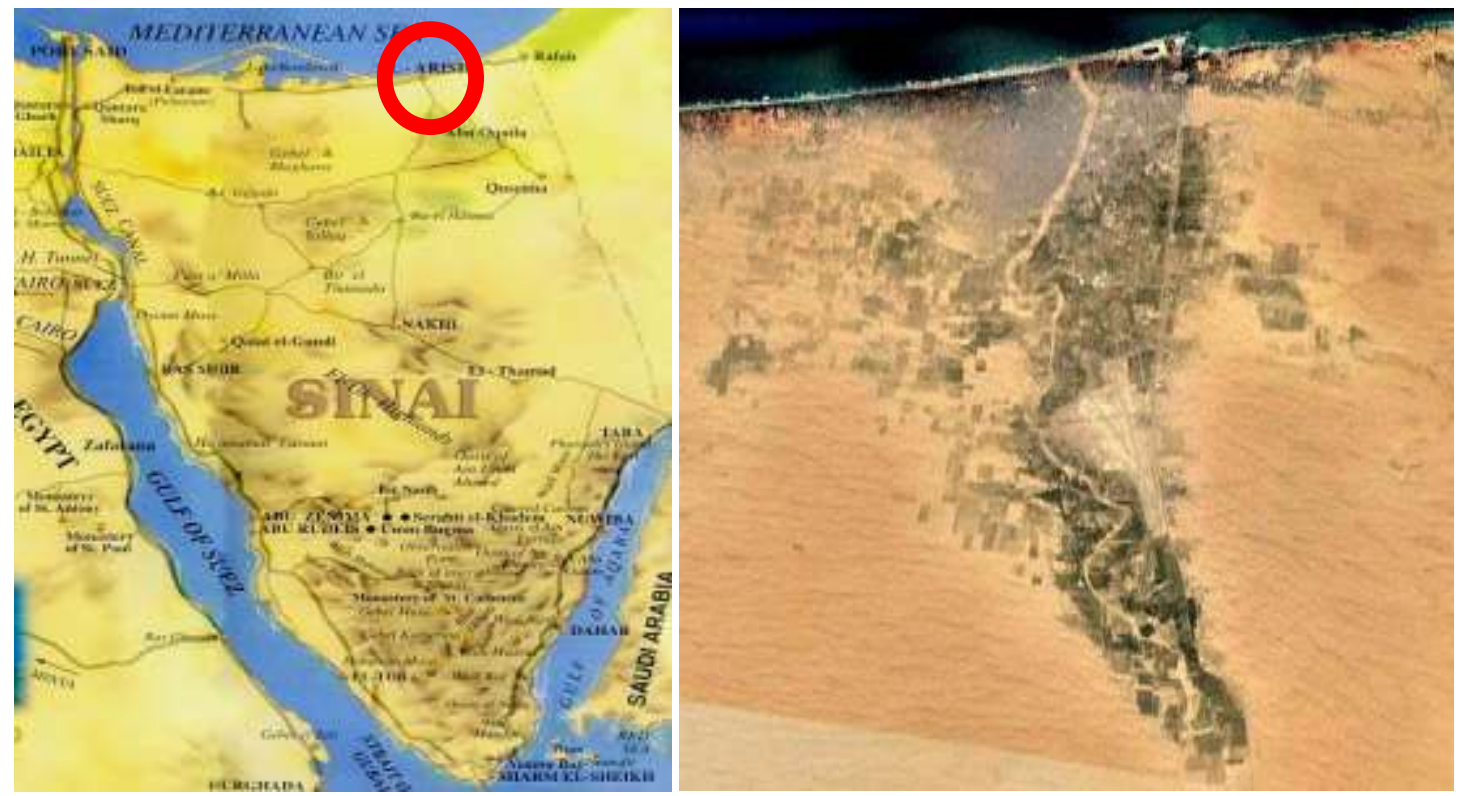

Arish is distinguished by its clear blue water, widespread fruitful palmy wood on its coast, and its soft white sand. It has a marina, and many luxury hotels. The city also has some of the faculties of Suez Canal University. The local economy is based on agriculture (date palms, castor beans), fishing, and quail trapping; there is a small castor-oil-producing plant. Commercial fishing in Lake Al-Bardawil began in the late 1970s. Coal deposits just to the south of the town are used to fuel an electric-power 
plant that was started in the early 1980s. The governorates offices are headquartered there, and the town has become a transfer point for materials passing between Egypt and Israel overland. The city is divided by a big valley called the Wadi el Arish, which receives flash flood water from much of north and central Sinai (Figure 1). The Azzaraniq national park is at the eastern side of Arish, it is a migratory bird's national park. (Figures $2 \& 3$ )

Figure (2) Existing land uses of Al-Arish City (GOPP 2010)

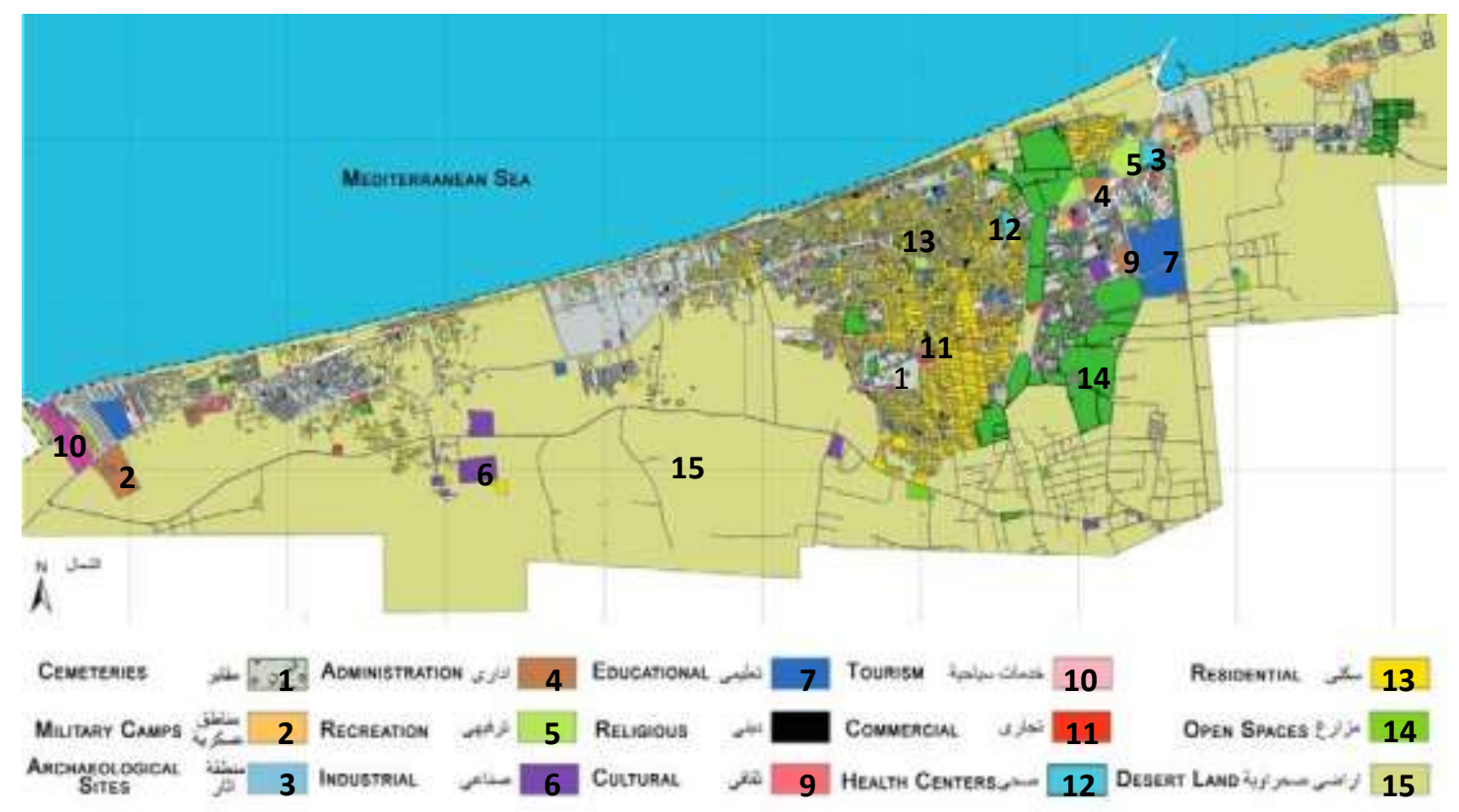

Figure (3) Palm features of the city and the Wadi (Hussein, H. M. 2012)
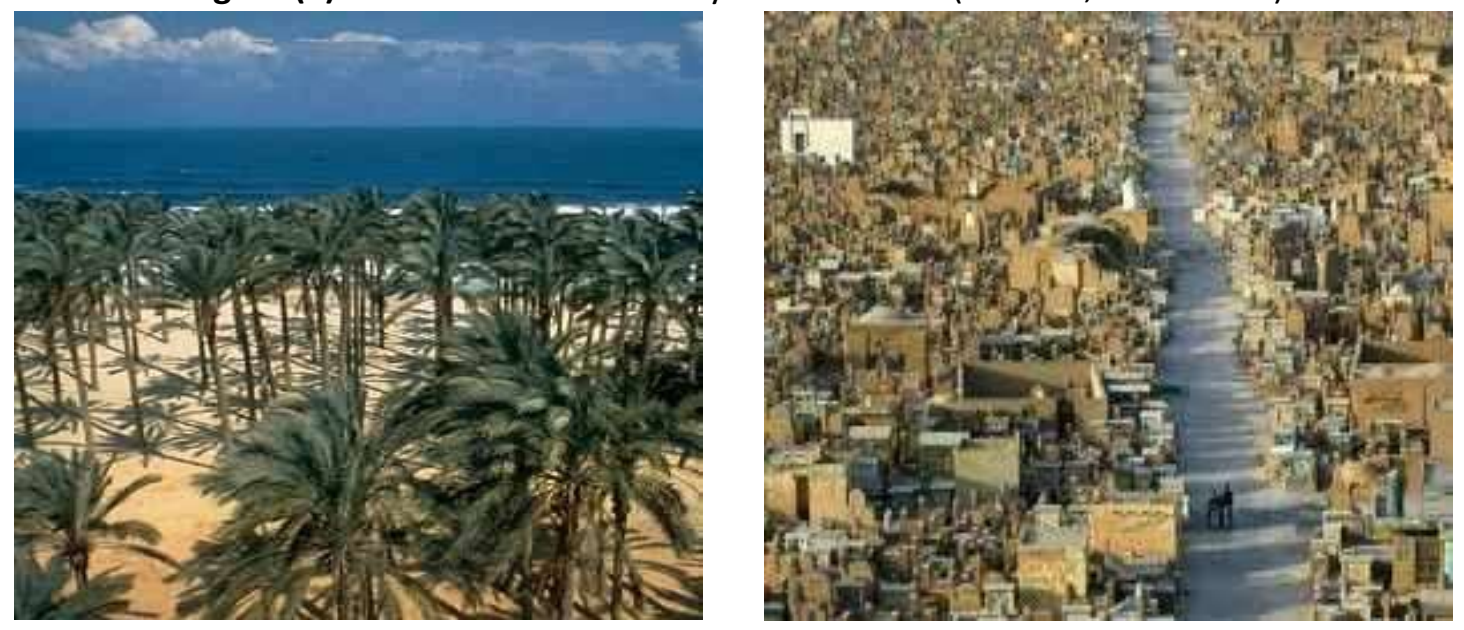

The Wadi Al-Arish landscape is now facing destruction at the hands of the rapid urbanization process that first set in during the early 1990s. The scenic and recreational properties of the landscape have been ignored entirely. This has disrupted the region's water balance and led to the pollution and destruction of wetlands. Habitats and species diversity are threatening to disappear, while the risk of floods, epidemics and drought is increasing, and the landscape's cultural identity is in danger of being lost. (Figure 4) 
Figure (4) Wadi landscape (Hussein, H. M. 2012)
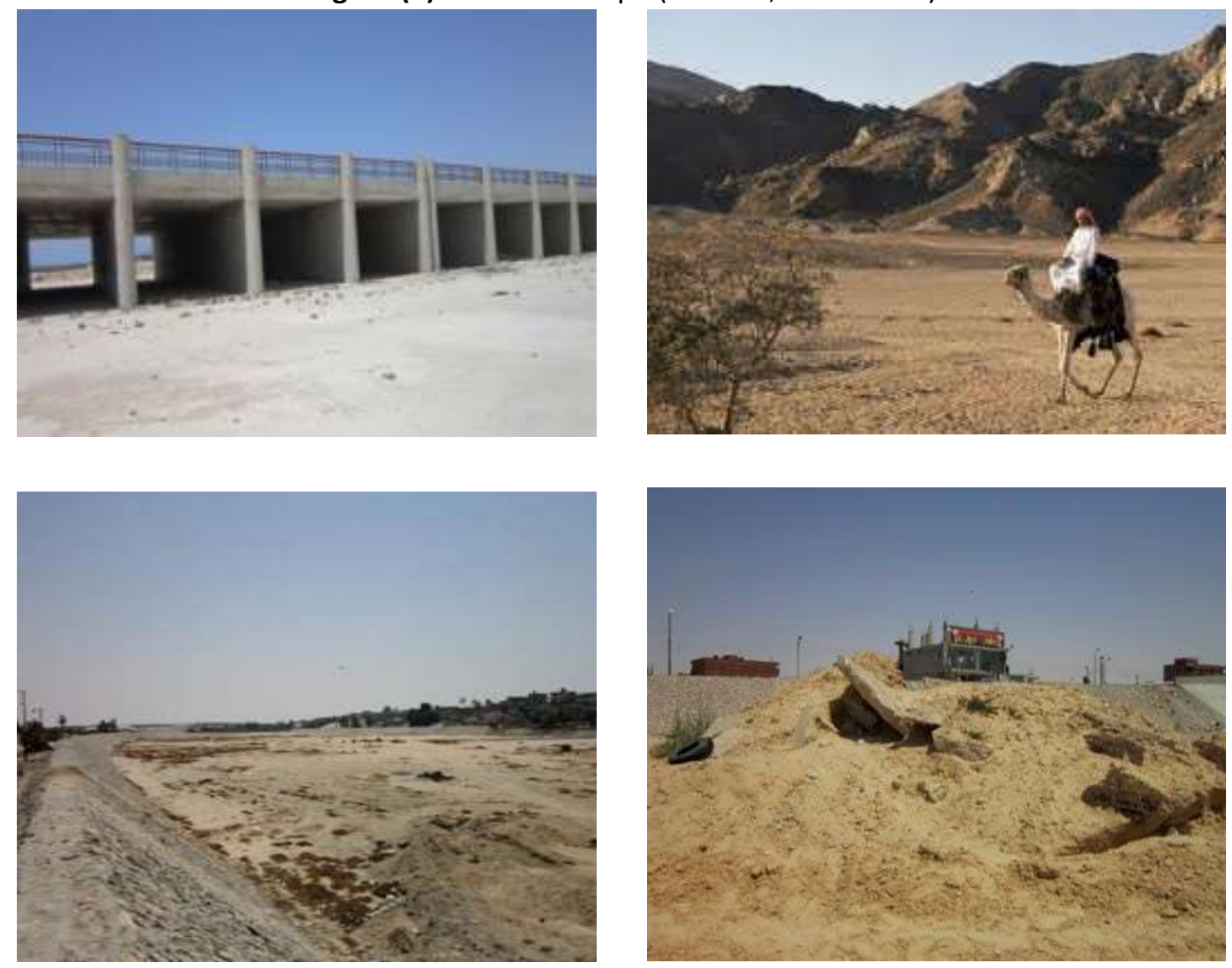

\subsection{Wadi El-Arish Landscape Features}

Wadi El-Arish is one of the most important geographical features of northern Sinai. Its basin is about $20000 \mathrm{~km}$ of Sinai in the Mediterranean drainage system. Its length is about $250 \mathrm{~km}$, narrow in its upper reaches through cutting across the El-Tih plateau (where the old pilgrimage road used to be). The Wadi is joined there by two tributaries, one from the west, wadi Al- Burak, and an eastern tributary, Wadi AlAqaba. Downstream other tributaries enter from both the east and west. (Abu Al-Izz, M., 1971) (Figure 5)

Wadi El-Arish can be divided into three sections: upper, central and lower (coastal). The upper section is about $100 \mathrm{~km}$ with a gradient of 6:1000. In the central section the wadi descends from $400 \mathrm{~m}$ to $150 \mathrm{~m}$ in about $100 \mathrm{~km}$, i.e., with gradient of 2.5:1000. The coastal section covers the last $50 \mathrm{~km}$ where the Wadi has a gradient of 3:1000. Along the Wadi, fluvial deposits from three terraces, having, at the town of El-Arish, elevations of 35, 22 and 13 m above sea level. (Abu Al-Izz, M., 1971)

The Wadi morphology can be analyzed in three sections. The upper section has a length of about $100 \mathrm{~km}$. and a gradient of $6: 1000$. In the central and northern sections the wadi descends from an elevation of $400 \mathrm{~m}$. to an elevation of $150 \mathrm{~m}$. in a distance of about $100 \mathrm{~km}$., i.e., with a gradient of $2.5: 1000$. The coastal section covers the last 
$50 \mathrm{~km}$. , where the wadi has a gradient of 3:1000. The wadi in its upper reaches crosses the high Tih Plateau and the southern section of the northeast-southwest Al-Maghara fold. In its central and northern sections the wadi crosses the upper portions of the northern folds. It changes in places from a consequent to an antecedent wadi. In other words, occasionally the stream has preserved its pretectonic course. (Zahran, M. and William, J. 1993) (Figure 6)

Figure (5) Landscape features of the Wadi (Hussein, H. M. 2012)

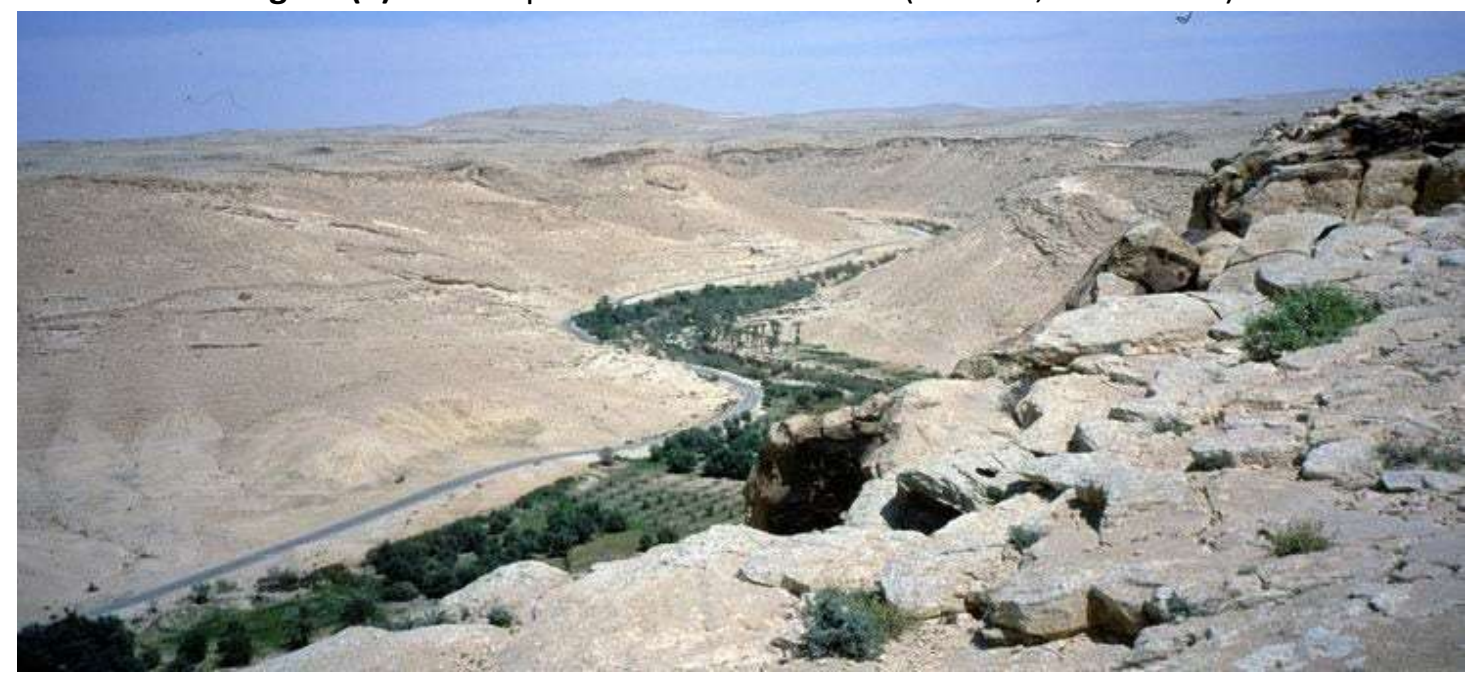

Figure (6) Wadi landscape morphology (Hussein, H. M. 2012)

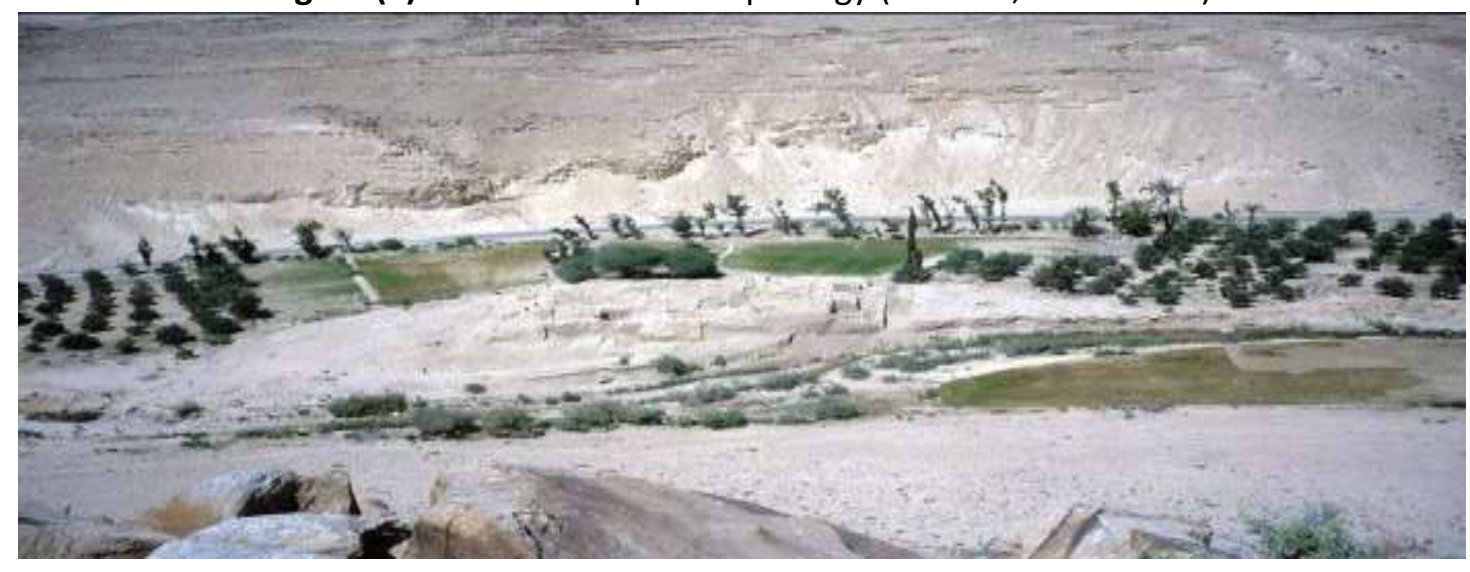

It has been mentioned that the hydrographic system in central and northern Sinai is affected by the geologic structure. Wadi Al-Burak parallels the laq-Halal fold, Wadi Maliz occupies a latitudinal depression between Mounts Um khushayb and Ya laq, and wadi hasane runs in another latitudinal between Mounts Ya laq and Halal. As just wadi Al-Arish is a consequent wadi in certain sections, but it is antecedent in others (in Dayyiqa Gorge where it cuts through the eastern part of the Halal fold). (Zahran, M. and William, J. 1993) (Figure 7)

The Dayyiqa Gorge is a water gap seven kilometers long. It is bordered by high walls of Cenomanian lime stones which rise about $150 \mathrm{~m}$. above the floor of the gorge. 
Evidently wadi Al-Arish, during the first stages of the formation of the gorge, managed to maintain its course across the Halal fold itself was in the making. Radial faulting facilitated this process. (Abu Al-Izz, M., 1971) The gradient of the wadi in the section of the Dayyiqa Gorge is $1: 400$. There is evidence that the gradient in the past was gentler. Excavations in 1947 showed that deposits of silt $45 \mathrm{~m}$. thick lie directly over the original rocks. This proved that the course of wadi Al-Arish has been deepened to about $40 \mathrm{~m}$. below its present level. Since we know that the altitude of the gorge at present is $170 \mathrm{~m}$. above sea level, then its altitude in the past must have been $130 \mathrm{~m}$. above sea level. In other words, the gorge was deeper and its gradient less it seems that gradient then was 1:2000. To the northeast of Al-Dayyiqa there is another gorge, known as Al- Rawafia, seven kilometers from the first. (Zahran, M. and William, J. 1993) (Figure 8)

Figure (7) Effect of geological structure on hydrological system of the Wadi (Hussein, 2012)
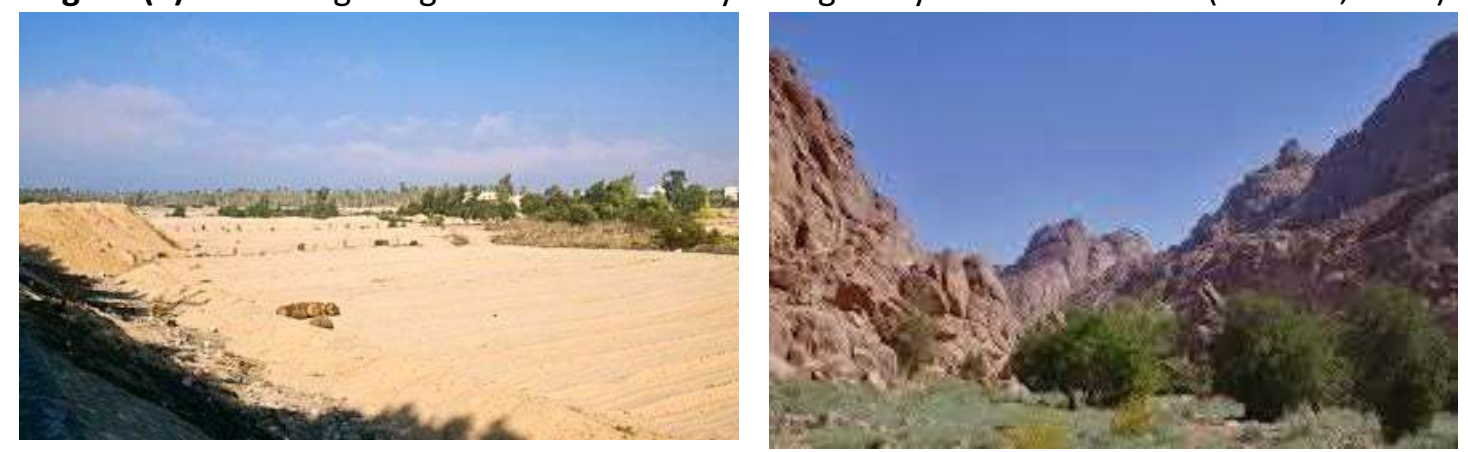

Figure (8) Vegetation and plant cover of the Wadi (Zahran, M. and William, J. 1993)
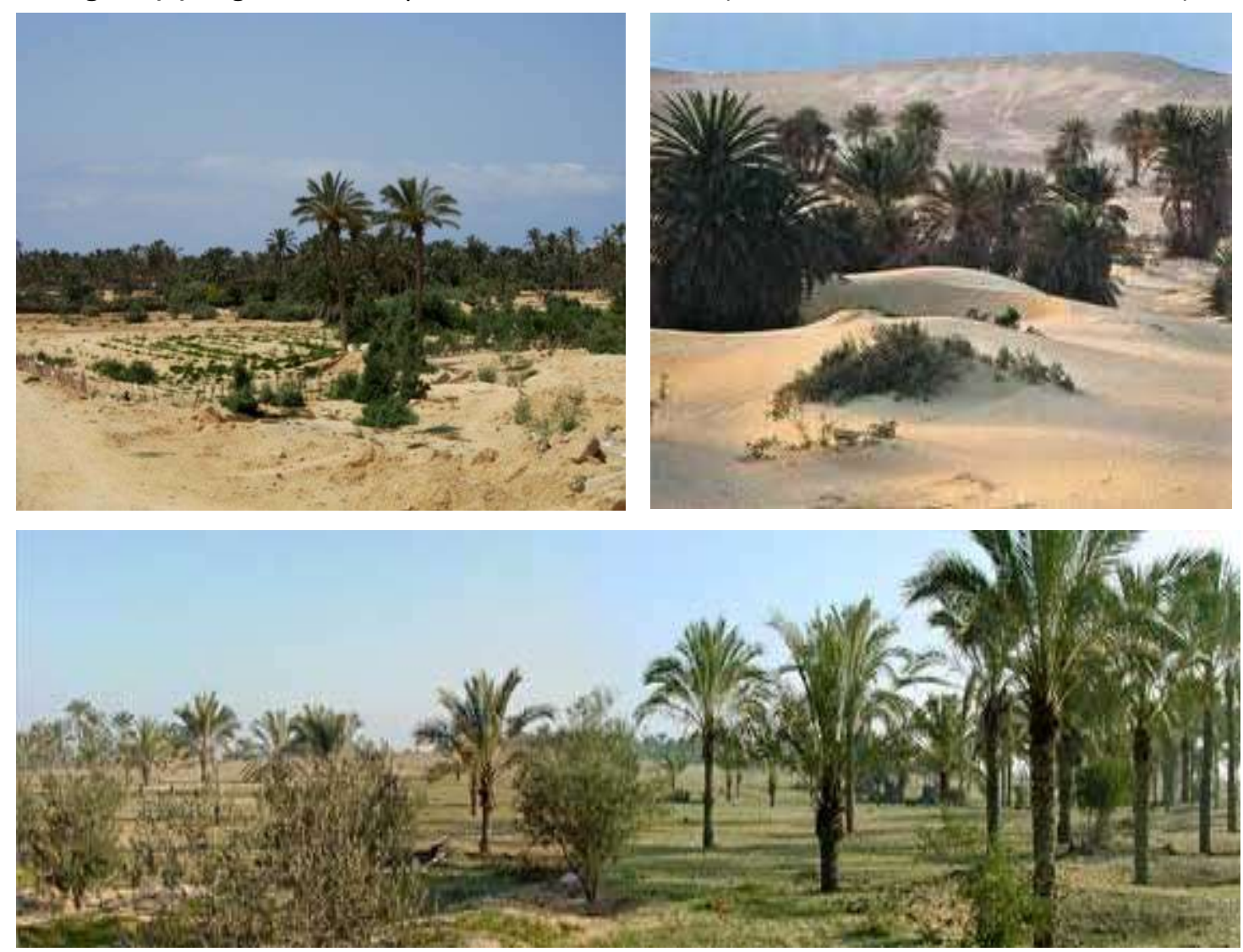
The presence of the two gorges indicates that wadi Al-Arish was subject to ponding south of Al-Dayyiqa. Shata has pointed out that both gorges were formed during the upper Pliocene or the Plio-Pleistocene, when northern Sinai was affected by tectonic movements (Abu Al-Izz, M., 1971). Wadi Al-Arish during the uplift was able to deepen its course through the Upper Cretaceous layers and also at the foothills of the highlands. The remainder of Wadi Al-Arish (between Al-Rawafia and the Mediterranean) runs for $50 \mathrm{~km}$. in a northwestern direction across a wide plain. Its course is characterized by broad meanders and is joined by small tributaries from both sides. Along the Wadi fluvial deposits from three terraces, having at the town of AlArish elevations of 35, 22, and $12 \mathrm{~m}$. above sea level At Abu Ugayla they are 25,

115 and $102 \mathrm{~m}$. above sea level. The level of recent deposits at the two locations is 92 $\mathrm{m}$. and $2 \mathrm{~m}$. respectively, indicating that the stream course used to be $33 \mathrm{~m}$.

higher. (Zahran, M. and William, J. 1993)

\subsection{Wadi El-Arish RPOSS Concept}

Wadi Al-Arish was chosen as a case study because it is treated as a left over or a negative space within the city. Due to the seasonal rains that comes on yearly bases and leads to the floods that lasts only two weeks per year. That was the main idea behind choosing it as a model to transform a negative open space within the region into a positive influential space within the city network system. (Figure 9)

Figure (9) Effect of 2010 water flood in the Wadi and its impact on the urban landscape (Hussein, H. M. 2012)
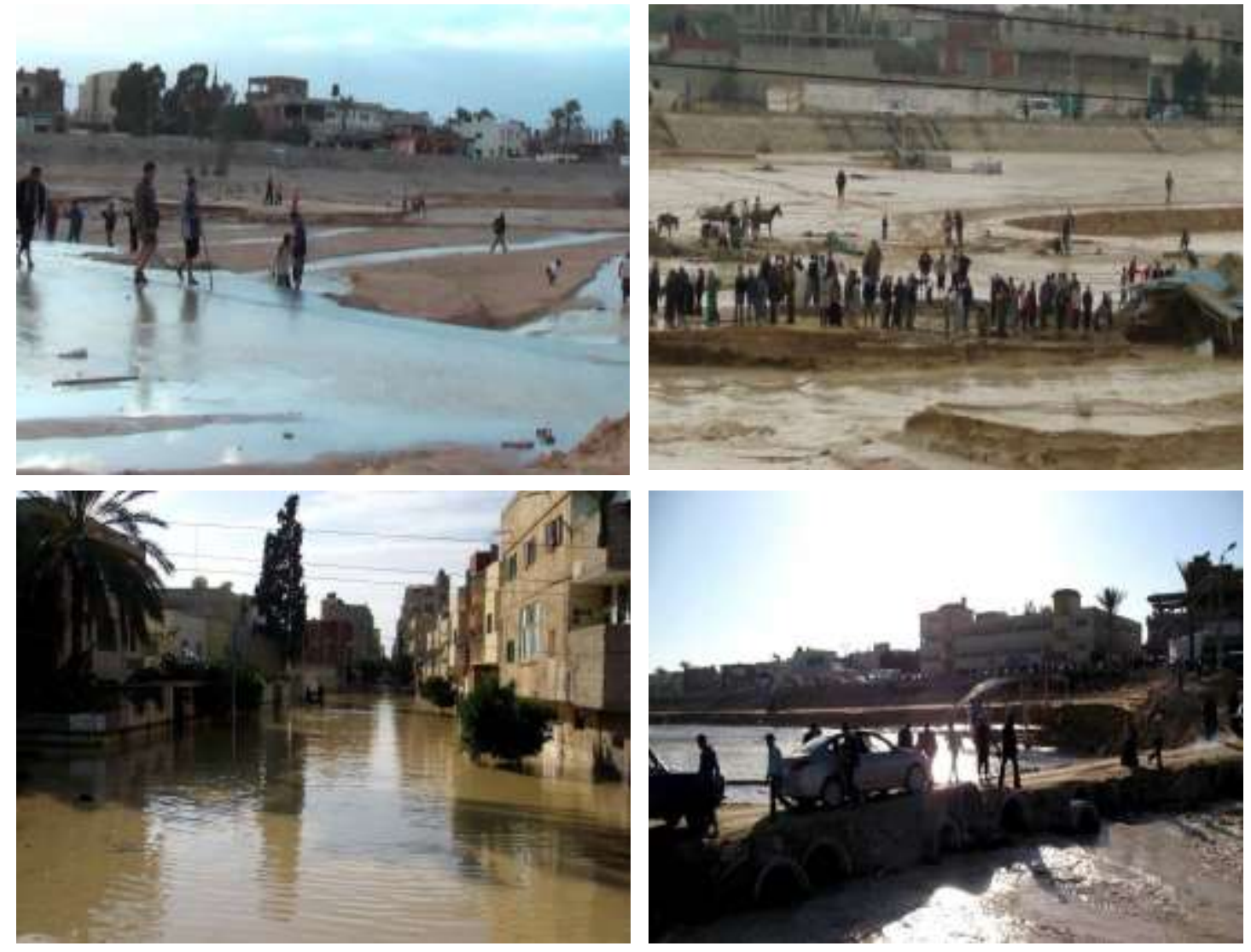
As mentioned earlier, ecology and planning have many common interests; ecology concerned with the functioning of resources, planning focusing on their appropriate use of human's benefit. Planning cannot be achieved without due consideration to ecology. Since the 1990s, alternative/future planning scenarios have been increasingly applied. Their use has proven effective in proactive strategic planning.

Landscape planning is a process through which to pursue biodiversity conservation. Well informed scientific analysis, linked with pragmatic politics in an effective planning process, may be used to guide plans which: are proactive instead of reactive; are visionary as well as pragmatic; are well founded in terms of research and understanding; are prescriptive, not just informative; are spatial, identifying and prioritizing specific areas and locations for protection and enhancement; are implementable, in terms of political support and available resources; use regulations and impact procedures as implementing tools; are comprehensive but not too detailed; are mid- to long-term in time-scale; overcome the inherent tendency of project-level regulation and assessment to fragment habitat; focus on planning for habitats and systems; provide a rational basis for coordinating project-specific mitigation requirements; provide effective financial mechanisms to compensate for significant losses of economic opportunity; build political consensus and public support through an open and accountable process; are cyclical, through monitoring and review; are binding, rather than simply advisory. (Mallarach,j. 2008)

To achieve these goals, a Natural Resources Inventory as a part of the master plan process was carried out as a basis for projects/proposals to restore degraded resources and maintain high-quality natural resource features including the estimated capital costs of natural resource restoration projects. Implementing agencies must consult with natural resource professionals in the design and final construction of park facilities, especially trails, that are adjacent to or cross over natural resource areas. The final design and construction should allow the public to view and enjoy these natural habitats with minimal adverse impact on that habitat. Also Information on how surface water and groundwater resources will be managed was carried out to understand as well as manage the water potentials of the Wadi. The main objective of the RPOSS concept is to lead stakeholders through decisions about priority ecosystem types and target species, and about the required physical conditions needed (including enough space and connectivity in the right location). (Forman, R. \& Gordon, M. 1986)

The proposed is a conceptual framework for sustainable landscape planning and design to form the operational objective, i.e. why, where, how and which landscape ecological concepts and metrics should be applied in planning. In order to form a coherent landscape planning concept the recreational activities to be accommodated by the regional park system should meet the following criteria: (Fabos, J.G.2004) (Figure 10)

1. Be strongly tied to high-quality natural resources and to the distribution of these resources around the area. 
2. Require a land supply and acquisition effort generally found the regional level.

3. Can be reasonably, feasibly and safely accommodated without detriment to existing uses or the environment as determined through master plans for facility improvements to accommodate the use, or through Regional Park implementing agency policy board decisions on park/trail use management issues.

Figure (10) Landscape Planning Concept for Wadi Al-Arish as a PROSS
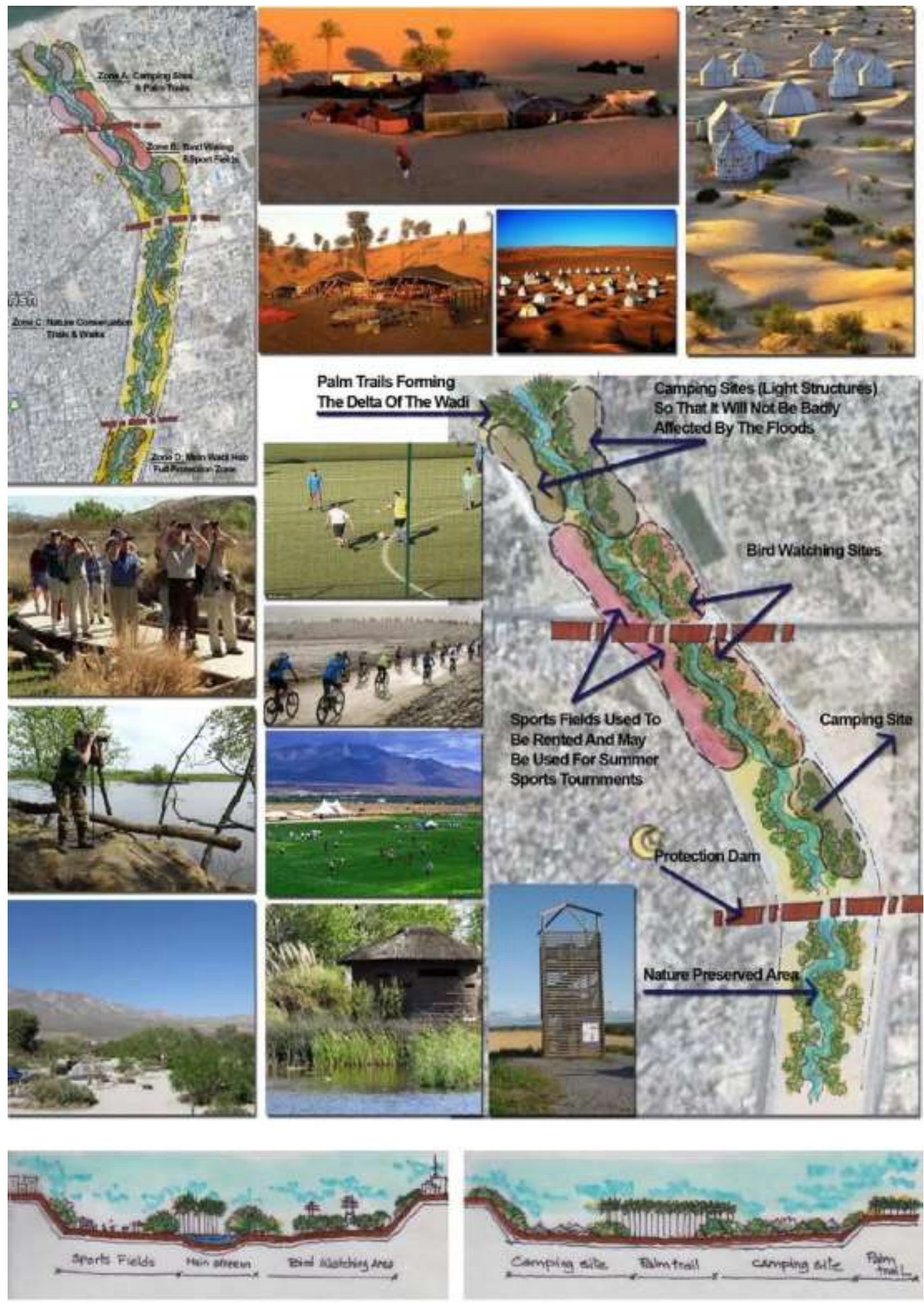
The prime activities that are hosted by the system are: picnicking, camping, sports fields, conservation, nature interpretation, and trail uses such as bird watching, walking, bicycling, and equestrian.

In conclusion the RPOSS must be developed that not only protects natural habitats and provides recreation areas but also gives settlements maximum protection from natural forces such as flooding, storms, and earthquakes and recognizes their importance as part of a cultural landscape and as home to many individuals. In addition it provides the landscape planning process with alternative ecological design options to choose between. Although it is worth considering that, one does not achieve sustainable conditions by simply offering a rational ecologically based landscape pattern that should be developed. The best ecological design option is not necessarily the plan that best corresponds with the peoples' feelings and with other functions' demands.

\section{CONCLUSIONS AND FINDINGS}

Many landscapes are visually reduced to such a state of poverty today, that the elementary conditions of perception are called into question. Today's landscape is no longer able to deliver relevant (aesthetical) knowledge to the beholder, who, in turn, is often aesthetically unsure because general aesthetic standards can hardly be found today. Landscape planning, one of the four principle currents for planning which also includes: social, public policy and economic planning. The main objective of landscape planning is the optimization of the distribution of land uses in an often limited space. Several researches have shown that promoting sustainability is the overarching goal of landscape (and regional) planning including planning for conservation, protection and appropriate use of land and natural resources. Sustainability is the major objective if any planning. Sustainability is multidimensional, involving the maintenance of natural resources and spatial patterns of land use that are ecologically, socially, and economically beneficial. Its spatial dimension is strongly related to the interdependence of land uses.

Sustainable landscape planning places physical planning in a broader perspective. Land (re)development is included to consider the improvement of ecological conditions for planned land uses. Also land management is included by adopting adaptive management techniques that apply monitoring as an important part of a sustainable landscape planning process.

Most researchers agree that preserving, creating, and restoring urban wildlife habitats has to be an interdisciplinary undertaking if it is to succeed. Ecologists and wildlife biologists must be key participants. The culturally modified context of most urban habitats suggests that landscape architects also have a primary role to play. Three general areas in which landscape architects have traditionally contributed to an interdisciplinary approach to urban wildlife habitat planning: contextual perspective, problem solving process, and design/technical execution.

New forms of holistic landscape planning for sustainability will, however, require a joined up delivery framework, necessitating increased levels of integration between 
the natural and social sciences, land and water managers, planners and policy makers across multiple landscape scales and levels of governance from landowner to national strategic governance. The basic objective of an open space system is to promote development that does not degrade environmental quality but, rather, enhances quality of the environment, quality of life, and quality of place by putting a focus on connectivity-that is to connect green elements, links and networks and then to manage development pressures and access to green spaces and wider green infrastructure. New landscapes emerge with changing life-styles. Decision making for landscape planning, conservation and management use the concept of sustainability widely. Therefore, the ever faster changes to landscapes are experienced by an increasing number of people as a threat. They feel uneasy in the new highly dynamic environment and may have difficulty adapting to a continuously changing landscape.

The main trends of actual landscape change are clear and indicate a polarization between more intensive and more extensive use of land. There is a continuing concentration of people and activities in rather small, highly intensive and densely crowded areas, while vast areas of land become disaffected or even abandoned.

In conclusion, we may state that there should be a need for greater integrated planning based on hydrological boundaries and the inclusion of socio-economic systems in parallel with environmental systems, as well as the incorporation of wider public participation in the land use planning process.

\section{References}

Abu Al-Izz, M (1971). Landforms of Egypt, American University Press, Cairo.

Ahern, J. (1999). Integration of landscape ecology and landscape design: An evolutionary process. In Issues in Landscape Ecology. pp. 119-123. Edited by J. A.

Andre Botequilha Leitao, Jack Ahren (2002), Challenges in integrating the concept of ecosystem services and values in landscape planning, management and decision making. Applying landscape ecological concepts and metrics in sustainable landscape planning, in Landscape ecology and urban planning 2002, p 65-93)

Bastian, O. and Röder, M. (1998). Assessment of landscape change by land evaluation of past and present situation. Landscape and Urban Planning 41: 163-170.

Beer, A. (1990). Environmental Planning for Site Development, Chapman \& Hall, New York

Carpenter, R.(1989). Natural Systems for Development: What Planner Need to Know. New York: Macmillan

Dames and Moore (1984). Sinai development study (phase I): Water resources., Vol. II-A and II-B: Report submitted to the Advisory Committee for Reconstruction, Ministry of Development, Cairo, Egypt (unpublished report).

Fabos J.G. (2004). Greenway planning in the United States: its origins and recent case studies. Landscape and urban planning, pp 321-342

Fabos J.G., and Robert Ryan (2004) International greenway planning: an introduction landscape and urban planning, Landscape and urban planning, pp 143-146 
Fabos, J. G (1985) Land Use Planning; From Global to Local Challenge, Chapman \& Hall, New York

Fahrig, L. (1999). When is a landscape perspective important? In Issues in Landscape Ecology. pp. 145-147. Edited by J. A. Wiens and M. R. Moss. International Association for Landscape Ecology, Guelph, Ontario, Canada.

Forman, R. \& Gordon, M. (1986). Landscape Ecology, John Wiley \& Sons, New York.

Hackett, B. (1971). Landscape Planning; an Introduction to Theory and Practice, Oriel Press, Newcastle upon Tyne.

Harms, B., Knaapen, J. P. and Rademakers, J. G. (1993). Landscape planning for nature restoration: comparing regional scenarios. In Landscape Ecology of a Stressed Environment. pp. 197-218. Edited by C. C. Vos and P. Opdam. Chapman \& Hall, London, UK.

Hobbs R, (1997). Future landscapes and the future of landscape ecology. Landscape and urban planning, pp 1-9

Hussein, E., M. Photographs of Al-Arish and its Wadi, Faculty of Urban and Regional Planning, Cairo University, Graduation Project Report 2012, Cairo, Egypt.

GENG Zhe et al., (2010) (Department of Landscape Architecture, Anhui Agricultural University, Hefei, Anhui: Analysis of the Establishment of Eco-trail System; Journal of Anhui Agricultural Sciences; -16

Jongman, A. H. G. and Troumbis, A. Y. (1996). The wider landscape for nature conservation: ecological corridors and buffer zones. MN2.7 Sub-Project Report. European Center for Nature Conservation, Tilburg

Li, B. L. (2000). Why is the holistic approach becoming so important in landscape ecology? Landscape and Urban Planning, 50: 27-41.

Mallarach, J. (2008) Protected landscapes and cultural and spiritual values, Kasparek Verlag, Heidelberg, Germany

McHarg, I. (1966), Design with Nature, J. Wiely \& Sons, New York

Naveh, Z. (2000). What is holistic landscape ecology? Landscape and Urban Planning, 50: 726.

Naveh, Z. (1984) Landscape Ecology; Theory and Application, Springer-Varlay, New York

North Sinai Governorate and the General Organization for Physical Planning (GOPP), The Strategic and Detailed Master Plan of the City of Al-Arish Report, 2010

Paul, Ruud Foppen, Claire Vos (2002). Bridging the gap between ecology and spatial planning in landscape ecology, Landscape Ecology, 16:767-779,

Takeuchi, K. and Lee, D. K. (1989). A framework for environmental management planning - A landscape-ecological approach. Landscape Ecology, 3: 53-63.

Turner, T. (1987) Landscape Planning, Hutshinson, London.

YU Hong et al., (2009). School of Gardening, Hunan Agricultural University, Changsha, Hunan Research Progress on Ecological Design of Urban Park; Journal of Anhui Agricultural Sciences; -18

Zahran, M. and William, J. (1993). The Vegetation of Egypt, Chapman and Hall, London. 